\title{
PEMBAHARUAN PENGUASAAN HAK ATAS TANAH DALAM PERSPEKTIF KONSTITUSI
}

\author{
(Renewing of Land Rights in Indonesia's Constitutional Perspective)
}

\author{
Anna Triningsih \\ Pusat Penelitian dan Pengkajian Perkara, Mahkamah Konstitusi Republik Indonesia \\ Jalan Medan Merdeka Barat Nomor 6 Jakarta \\ Email: annatriningsih@mkri.id \\ Zaka Firma Aditya \\ Pusat Penelitian dan Pengkajian Perkara, Mahkamah Konstitusi Republik Indonesia \\ Jalan Medan Merdeka Barat Nomor 6 Jakarta \\ Email: zaka.firma@mkri.id
}

Naskah diterima: 9 September 2019; revisi: 8 November 2019; disetujui: 8 November 2019

\begin{abstract}
Abstrak
Pasal 33 ayat (3) UUD 1945 mengamanatkan kepada negara bahwa segala sesuatu yang berkaitan dengan tanah sebagai bagian dari bumi, air dan kekayaan alam yang terkandung di dalamnya yang ada di Indonesia harus dan wajib untuk dikelola dan dimanfaatkan bagi sebesar-besarnya kemakmuran rakyat Indonesia. Hak menguasai negara khususnya dibidang pertanahan merupakan hak yang diberikan kepada negara untuk pengurusan (bestuursdaad), pengaturan (regelendaad), pengelolaan (beheersdaad), dan pengawasan (toezichthoudensdaad). Penelitian ini merupakan penelitian hukum dengan metode hukum normatif yang bersifat preskriptif, yang menjelaskan mengenai penguasaan hak atas tanah dalam perspektif konstitusi dalam putusan-putusannya. Mahkamah Konstitusi memiliki peranan dalam memberikan kontribusi pembaharuan hukum agraria (dalam arti luas), yang dituangkan melalui putusan-putusan tentang pengujian Undang-Undang terhadap Undang-Udang Dasar 1945, antara lain mengenai privatisasi minyak dan gas bumi dalam Putusan Mahkamah Konstitusi Nomor 002/PUU- 1/2003, mengenai kewenangan daerah di bidang pertanahan dalam Putusan Mahkamah Konstitusi Nomor 009/PUU-I/2003 dan mengenai ketentuan masa berlakunya Hak Guna Usaha, Hak Guna Bangunan, Hak Pakai hak-hak atas tanah pada Pasal 22 UU Nomor 25 Tahun 2008 tentang Penanaman Modal dalam Perkara Mahkamah Konstitusi Nomor 21-22/PUU-V/2007. Oleh karena Mahkamah Konstitusi merupakan lembaga peradilan yang diberi kedudukan sebagai penafsir tertinggi (the ultimate interpreter) serta sebagai penjaga konstitusi (the guardian of the constitution) agar undang-undang harus bersesuaian dengan konstitusi, tanpa ada lagi ketentuan perundang-undangan beserta penjelasannya yang bertentangan Undang-Undang Dasar 1945.
\end{abstract}

Kata Kunci: pembaharuan, penguasaan, hak atas tanah, Mahkamah Konstitusi

\begin{abstract}
Article 33 paragraph (3) of the Constitution of the Republic of Indonesia mandates the state that everything related to land as part of the earth, water and natural resources contained therein in Indonesia must be managed and utilized for the greatest prosperity of the people of Indonesia. The right to control the state, especially in the field of land is a right granted to the state for management (bestuursdaad), regulation (regelendaad), management (beheersdaad), and supervision (toezichthoudensdaad). This research is a legal research with prescriptive normative legal methods, which explains the control of land rights in the perspective of the constitution in its decisions. The Constitutional Court has a role in contributing to the renewal of agrarian law (in the broad sense), as outlined in decisions on the review of the Law on the 1945 Basic Shrimp, including the privatization of oil and gas in the Constitutional Court Decision Number 002 / PUU - I / 2003, regarding regional authority in the field of land in the Constitutional Court Decision Number 009 / PUU-I / 2003 and concerning the provisions for the validity of the Cultivation Right of Cultivation, Right to Build, Right to Use land rights in Article 22 of Law Number 25 Year 2008 concerning Investment in the Case of the Constitutional Court Number 21-22 / PUU-V / 2007. Because the Constitutional Court is a judicial institution that is given the position of the highest interpreter (the ultimate interpreter) and as the guardian of the constitution (the guardian of the constitution) so that the law must be in accordance with the constitution, with no more statutory provisions that contradict the Law Basic 1945.

Keywords: renewal, control, land rights, Constitutional Court of the Republic of Indonesia
\end{abstract}




\section{A. Pendahuluan}

Negara Indonesia sebagai negara yang menegaskan dirinya sebagai "negara agraris" menempatkan tanah pada kedudukan yang teramat penting. Begitu pentingnya tanah, sehingga konstitusi memberikan amanat kepada negara untuk melindunginya. Hal ini dinyatakan secara tegas dalam Pasal 33 ayat (3) Undang-Undang Negara Republik Indonesia Tahun 1945 yang menegaskan bahwa "Bumi, air dan kekayaan yang terkandung di dalamnya dikuasai oleh negara untuk sebesar-besar kemakmuran rakyat". Mandat konstitusional tersebut mengamanatkan kepada negara bahwa segala sesuatu yang berkaitan dengan tanah sebagai bagian dari bumi, air dan kekayaan alam yang terkandung di dalamnya yang ada di Indonesia harus dan wajib untuk dikelola dan dimanfaatkan bagi sebesarbesarnya kemakmuran rakyat Indonesia.

Apabila ditelusuri sejarah hukumnya, pembentukan Pasal 33 ayat (3) UUD 1945 merupakan gagasan Soepomo yang mengemukakan konsep Negara integralistik dalam pidato di depan sidang BPUPKI pada tanggal 31 Mei 1945. Menurutnya, dalam Negara integralistik yang berdasar atas persatuan, maka dalam lapangan ekonomi akan dipakai sistem Sosialisme Negara (Staats Socialisme). Oleh karena itu, perusahaanperusahaan yang penting dan menguasai hajat hidup rakyat banyak akan diurus oleh Negara sendiri. Negara menjadi pelaku tunggal yang akan menentukan dimana, dimasa apa, perusahaan apa yang akan diselenggarakan oleh pemerintah pusat atau oleh pemerintah daerah atau yang akan diserahkan pada suatu badan hukum privat atau kepada seseorang, itu semua tergantung dari pada kepentingan Negara atau kepentingan rakyat seluruhnya. Begitu juga tentang tanah yang pada hakekatnya Negara yang menguasai tanah seluruhnya. Sehingga segala hal yang berkaitan dengan tanah termasuk pertambangan yang penting untuk Negara akan diurus oleh Negara sendiri. ${ }^{1}$

Amanat kepada negara untuk melindungi tanah juga diatur secara yuridis melalui Undang-Undang Nomor 5 tahun 1960 tentang Peraturan Pokok-Pokok Agraria (UUPA). Dalam Pasal 2 ayat (2) UUPA disebutkan bahwa negara memiliki hak dan berwenang untuk:

a) mengatur dan menyelenggarakan peruntukan, penggunaan, persediaan dan pemeliharaan bumi, air dan ruang angkasa tersebut;

b) menentukan dan mengatur hubunganhubungan hukum antara orang-orang dengan bumi, air dan ruang angkasa;

c) menentukan dan mengatur hubunganhubungan hukum antara orang-orang dan perbuatan-perbuatan hukum yang mengenai bumi, air dan ruang angkasa.

Selanjutnya, pada Pasal 2 ayat (3) UUPA ditegaskan juga bahwa wewenang yang bersumber pada hak menguasai dari Negara tersebut digunakan untuk mencapai sebesar-besar kemakmuran rakyat dalam arti kebangsaan, kesejahteraan dan kemerdekaan dalam masyarakat dan Negara hukum Indonesia yang merdeka, berdaulat, adil dan makmur. Hak menguasai dari Negara tersebut di atas pelaksanaannya dapat dikuasakan kepada daerah-daerah Swatantra dan masyarakat-masyarakat hukum adat, sekedar diperlukan dan tidak bertentangan dengan

Lihat Muhammad Bakri, Hak Menguasai Tanah oleh Negara: Paradigma Baru untuk reformasi Agraria, cetakan 1 (Yoyakarta: Citra Media, 2007), hlm. 35. 
kepentingan nasional, menurut ketentuanketentuan Peraturan Pemerintah.

Hak Menguasai Negara Atas Tanah adalah sebutan yang diberikan oleh undang-undang pokok agraria kepada lembaga hukum dalam hubungan hukum kongkret antara negara dan tanah indonesia yang dirinci isi dan tujuanya dalam Pasal 2 ayat (2) dan (3) UUPA. ${ }^{2}$ Hak Menguasai dari Negara posisinya berada dibawah Hak Bangsa. Terjadinya adalah sebagai pelimpahan tugas kewenangan Bangsa Indonesia, yang dilakukan oleh wakilwakil bangsa indonesia pada waktu menyusun Undang-undang dasar Negara republik indonesia tahun 1945 dan membentuk negara Indonesia pada tanggal 18 Agustus 1945. Pelimpahan tugas tersebut dituangkan dalam Pasal 33 ayat (3) Undang-undang dasar Negara Republik Indonesia tahun $1945 .^{3}$ Pelimpahan itu dilakukan dengan maksud agar Bangsa Indonesia yang diproklamasikan pada tanggal 17 Agustus 1945 dapat mencapai tujuan pendiriannya yakni untuk mencapai Indonesia yang adil dan makmur. ${ }^{4}$

Akan tetapi di dalam pelaksanaannya, ternyata penerapan UUPA yang pada awalnya bersifat nasionalis, populis, dan mendasarkan pada hukum asli Indonesia tidak sama sebagaimana seperti tujuan pembentukannya. Hal ini dapat diketahui dari banyaknya penyimpangan UUPA yang kemudian mendorong MPR mengeluarkan Ketetapan MPR Nomor IX Tahun 2001 tentang Reformasi Agraria dan Pengelolaan Sumber Daya Alam (SDA), yang merupakan landasan peraturan perundang-undangan di bidang pembaharuan agraria dan pengelolaan sumber daya alam. ${ }^{5}$ Diperlukannnya Reformasi Agraria dan Pengelolaan Sumber Daya Alam (SDA) disebabkan adanya undang-undang sektoral menjadi degradasi terhadap UUPA yang pada awalnya dimaksudkan untuk menjadi aturan yang bersifat umum (lex generalis) bagi pengaturan Sumber Daya Alam (SDA) menjadi sederajat dengan undang-undang sektoral lainnya dan dengan demikian menjadikan UUPA sebagai aturan yang bersifat khusus (lex specialis) yang hanya mengatur bidang pertanahan. Ditinggalkannya semangat dan prinsip-prinsip yang mendasari UUPA oleh undang-undang sektoral dapat ditengarai dalam perbedaan antara UUPA dengan undang-undang sektoral berkaitan dengan: 1) orientasi; 2) keberpihakan; 3)pengelolaan dan implementasinya; 4) perlindungan Hak Asasi Manusia (HAM); 5) pengaturan good governance; 6) hubungan orang dengan Sumber Daya Alam; dan 7) hubungan antara negara dengan Sumber Daya Alam. ${ }^{6}$

Selain itu, terdapat juga beberapa permasalahan lain berupa salah tafsir dalam penerapan UUPA selama ini, yakni: (1)

2 Budi Harsono, Hukum Agraria Indonesia, Sejarah Pembentukan Undang-undang Pokok Agraria Isi Dan Pelaksanaannya, (Jakarta: Penerbit Djambatan, 1995), hlm. 268.

Ibid., hlm 273.

Ibid., hlm. 267.

5 Keluarnya Ketetapan MPR Nomor IX Tahun 2011 berperan sebagai landasan kebijakan pertanahan nasional, termasuk pengaturan hak masyarakat hokum adat dalam pemanfaatan tanah. Meskpun demikian, Achmad Sodiki mengatakan bahwa meskipun kekayaan alam sudah dikuras habis, namun masyarakat tetap tidak merasakan manfaatnya. Lihat, Achmad Sodiki, "kebijakan Sumber Daya Alam dan Implikasi Yuridisnya Pasca Ketetapan MPR Nomor IX Tahun 2001 dan KepPres Nomor 34 Tahun 2003", Makalah disampaikan pada Seminar Nasional "Eksistensi Kewenangan BPN Pasca Keppres Nomor 34 Tahun 2003", Malang, hlm. 8.

6 Maria Sumardjono, dkk., Pengaturan Sumber Daya Alam di Indonesia, Antara yang Tersurat dan Tersirat, (Yogyakarta: Gadjah Mada University Press, 2011) 
penafsiran pengerian hak menguasai negara yang sangat luas, dimana negara dipersepsikan sebagai pemilik semua tanah7; (2) beragamnya penasiran "tanah negara" dan berbagai implikasi yuridisnya; (3) Pembelokan hak pengelolaan sehingga lebih menonjolkan sifat keperdataannya; (4) longgarnya penafsiran "fungsi sosial" hak atas tanah sehingga menimbulkan ketidakseimbangan antara kepentingan umum dengan kepentingan perseorangan; (5) perlindungan dan pengakuan hak masyarakat adat yang tidak tuntas dan kurangnya perlindungan terhadap hak ulayat; (6) pengabaian nilai-nilai lain dari tanah dimana tanah hanya dipandang dari segi ekonomis saja telah menjadikan tanah sebagai komoditas dan alat untuk akumulasi modal. ${ }^{8}$

Tulisan ini akan memfokuskan pada permasalahan pertama dalam penerapan UUPA diatas, yakni berkaitan dengan penafsiran mengenai hak menguasai negara yang di dalam prakteknya ditafsirkan sangat luas. Bahkan menurut Erwiningsih, kekuasaan negaraatastanah sangatmudah diberikantafsir tunggal sesuai dengan keinginan penguasa. ${ }^{9}$ Pembahasan dalam tulisan ini akan menarik karena penulis hendak mengkaji mengenai penguasaan hak atas tanah dalam perspektif konstitusi dengan menggunakan pendekatan kasus yakni menggunakan putusan-putusan
Mahkamah Konstitusi. Ditambah lagi, selain UUPA ternyata banyak undang-undang lainnya yang mengatur hak menguasai negara dibidang pertanahan, antara lain: UndangUndang Nomor 11 Tahun 1967 tentang Peraturan Pokok-Pokok Pertambangan, Undang-Undang Nomor 3 Tahun 1972 tentang Peraturan Pokok-Pokok Transmigrasi, Undang-Undang Nomor 11 Tahun 1974 tentang Pengairan, Undang Undang Nomor 4 tahun 1996 tentang Hak Tanggungan; Undang Undang Nomor 23 Tahun 1997 tentang Penataan Lingkungan Hidup; Undang Undang Nomor 22 Tahun 2001 tentang Minyak dan Gas Bumi; Undang Undang Nomor 25 Tahun 2007 tentang Penanaman Modal dan Undang Undang Nomor 10 Tahun 1997 tentang Ketenaganukliran. Tulisan ini akan membahas dua permasalahan secara mendalam, yakni (1) Bagaimana penguasaan hak atas tanah dari segi yuridis-teoritis; dan (2) bagaimana penguasaan hak atas tanah dalam beberapa putusan Mahkamah Konstitusi.

\section{B. Metode Penelitian}

Penelitian ini merupakan penelitian hukum dengan metode hukum normatif yang bersifat preskriptif. Menurut Peter Mahmud Marzuki, di dalam penelitian hukum umumnya dikenal beberapa pendekatan penelitian yakni: pendekatan undang-undang

Hak menguasai oleh Negara sebenarnya memiliki semangat pengganti asas "domein verklaring" yang berlaku pada masa kolonial belanda, yang ternyata hanya memberikan keuntungan pada pemerintahan kolonial belanda pada masa itu. Asas domein verklaringtercantum di dalam Agrarisch Besluit (Staatsblad 1870 Nomor 118) sebagai aturan pelaksana AgrarischWet (AW 1870). Secara gramatikal, "Domein" berarti wilayah atau tanah milik negara dan "verklaring" berarti pernyataan. Jadi, "Domen Verklaring" artinya penyataan bahwa suatu tanah yang tidak dapat dibuktikan pemiliknya dianggap sebagai tanah negara. Ridwan Halim, Hukum Agraria dalam Tanya Jawab, (Jakarta: Ghalia Indonesia), hlm. 18.

8 Lihat Okky Chahyo Nugroho, "Konflik Agraria di Maluku di Tinjau Dari Perspektif Hak Asasi Manusia", Jurnal HAM Volume 9(1) Juni 2018, hlm. 88-89.

9 Winahyu Erwiningsih, "Pelaksanaan Pengaturan Hak Menguasai Tanah Negara atas Tanah Menurut UUD 1945", Jurnal Hukum Edisi Khusus Volume 16, Oktober 2009, hlm. 120. 
(statute approach), pendekatan konseptual (conceptual approach), pendekatan kasus (case approach), pendekatan perbandingan (comparative approach) dan pendekatan sejarah (historical approach). Tulisan ini menggunakan pendekatan undang-undang (statute approach), pendekatan perbandingan (comparative approach) dan pendekatan sejarah (historical approach). ${ }^{10}$

Pendekatan undang-undang (statute approach) dilakukan dengan menelaah semua peraturan perundang-undangan yang bersangkut paut dengan isu yang sedang dikaji yakni undang-undang dan regulasi yang berhubungan hak menguasai negara dalam bidang pertanahan. Pendekatan kasus (case approach) berkaitan dengan putusan-putusan pengadilan (putusan mahkamah konstitusi) yang berkaitan dengan isu dalam bidang pertanahan khususnya mengenai penguasaan hak atas tanah.

\section{Pembahasan}

\section{Penguasaan Hak Atas Tanah dalam Perspektif Yuridis-Teoritis}

Secara teoritis, frasa "dikuasai oleh negera" mengandung arti mengatur dan/ atau menyelenggarakan terutama untuk memperbaiki dan mempertimbangkan produksi sumber daya alam tersebut. Selain itu, Mohammad Hatta juga merumuskan pengertian "dikuasai oleh negara" mengandung arti bahwa negara tidak menjadi pengusaha atau usahawan, akan tetapi lebih tepat dikatakan bahwa kekuasaan negara terdapat pada membuat peraturan guna kelancaran jalan ekonomi, peraturan tersebut juga melarang adanya pemanfaatan orang yang lemah oleh orang yang mempunyai modal. ${ }^{11}$ Sementara itu, Yance Arizona dalam tulisannya berjudul "Perkembangan Konstitusionalitas Penguasaan Negara Atas Sumber Daya Alam dalam Putusan Mahkamah Konstitusi" mengatakan bahwa tafsiran MK terhadap Pasal 33 UUD Tahun 1945 harus dimaknai bahwa adanya sebuah aturan yang mengamanatkan untuk memberikan kemakmuran bagi sebesar-besarnya kepada rakyat. Oleh karena itu, dapat dikatakan bahwa Hak menguasai yang diberikan oleh UUD Tahun 1945 kepada negara bukan demi negara sendiri melainkan dipergunakan bagi sebesar-besar kemakmuran rakyat. Bagi orang perorangan pemegang hak atas tanah, termasuk badan hukum, penegasan tersebut memberi kepastian bahwa dalam hak atas tanah yang dipunyainya itu melekat pula pembatasan-pembatasan yang lahir dari adanya hak penguasaan oleh Negara. Bagi pihak-pihak lain yang bukan pemegang hak atas tanah juga diperoleh kepastian bahwa mereka tidak serta-merta dapat meminta negara untuk melakukan tindakan penguasaan atas tanah yang terhadap tanah itu sudah melekat suatu hak tertentu. ${ }^{12}$

Iman Soetikno dalam bukunya berjudul "Politik Agraria Nasional" memberikan pengertian hak menguasai Negara yang sejatinya dapat dibagi menjadi 2 (dua) bagian yakni: (1) hak menguasai aktif dan (2) hak

\footnotetext{
10 Peter Mahmud Marzuki, Penelitian Hukum (Jakarta: Kencana Media Group, 2014), hlm. 93.

11 Mohammad Hatta, Penjabaran Pasal 33 Undang-Undang Dasar 1945, (Jakarta: Mutiara, 1977), hlm. 28.

12 Yance Arizona, "Perkembangan Konstitusionalitas Penguasaan Negara Atas Sumber Daya Alam dalam Putusan Mahkamah Konstitusi", Jurnal Konstitusi, Vol. 8, No. 3, Juni 2011, hlm. 308.
} 
menguasai pasif. ${ }^{13}$ Hak menguasi aktif adalah hak menguasi dari negara yang meliputi tanah dengan hak-hak perorangan, apabila tanah tersebut dibiarkan tidak diurus/ditelantarkan. Hak menguasai dari negara atas tanah yang tidak dipunyai oleh perorangan atau keluarga dengan hak apapun, dan masih belum dibuka juga dapat digolongkan sebagai hak penguasaan bersifat aktif. ${ }^{14}$ Sedangkan hak menguasai pasif adalah hak menguasi dari negara yang meliputi tanah dengan hak-hak perorangan bersifat pasif", artinya bahwa diatas tanah telah ada hak-hak perorangan ataupun keluarga, maupun hak-hak yang lainnya. ${ }^{15}$

Secara yuridis, Selain memberikan kewenangan kepada Pemerintah untuk menguasai tanah dengan mendaftarkan kepemilikan hak atas tanah seseorang, UUPA juga memberikan kewenangan kepada pemilik hak atas tanah untuk mengelola dan memanfaatkan tanahnya tersebut sebagaimana diatur di dalam Pasal 4 UUPA. Menurut ketentuan Pasal 4 ayat (1) UUPA, hak menguasai dari Negara sebagaimana yang dimaksud dalam pasal 2 UUPA ditentukan adanya macam-macam hak atas permukaan bumi, yang disebut tanah, yang dapat diberikan kepada dan dipunyai oleh orangorang, baik sendiri maupun bersama-sama dengan orang-orang lain serta badan-badan hukum. Selanjutnya, dalam penjelasannya ditegaskan bahwa tanah adalah permukaan bumi. Secara lengkap penjelasan UUPA mendeskripsikan bahwa dalam pada itu hanya permukaan bumi saja, yaitu tanah, yang dapat menjadi hak seseorang. Sementara itu, Pasal 4 ayat (2) UUPA menentukan bahwa hak-hak atas tanah yang dimaksud dalam ayat (1) pasal ini memberi wewenang untuk mempergunakan tanah yang bersangkutan, demikian juga tubuh bumi dan air serta ruang yang ada diatasnya, sekedar diperlukan untuk kepentingan yang langsung berhubungan dengan penggunaan tanah itu dalam batasbatas menurut undang-undang ini dan peraturan-peraturan hukum lain yang lebih tinggi.

Namun sesungguhnya penguasaan hak atas tanah tidak hanya diatur dalam UUPA saja, melainkan juga di dalam beberapa undang-undang lainnya. Menurut Undang Undang Nomor 41 Tahun 1999 tentang Kehutanan, Penguasaan hutan oleh Negara bukan merupakan pemilikan, tetapi Negara memberi wewenang kepada pemerintah untuk mengatur dan mengurus segala sesuatu yang berkaitan dengan hutan, kawasan hutan dan hasil hutan; menetapkan kawasan hutan dan atau mengubah status kawasan hutan; mengatur dan menetapkan hubungan hukum antara orang dengan hutan atau kawasan hutan dan hasil hutan, serta mengatur perbuatan hukum mengenai kehutanan. Selanjutnya pemerintah juga memiliki wewenang untuk memberikan izin dan hak kepada pihak lain untuk melakukan kegiatan di bidang kehutanan.

Pasal 4 Undang Undang Nomor 41 Tahun 1999 tentang Kehutanan menentukan bahwa:

\footnotetext{
13 Iman Soetikno, Politik Agraia Nasional, (Yogyakarta: Gadjah Mada Univcersity press, cetakan ketiga,1990), hlm. 53.

14 Ibid.

15 Ibid.
} 
1. Semua hutan di dalam wilayah Republik Indonesia termasuk kekayaan alam yang terkandung di dalamnya dikuasai oleh Negara untuk sebesar-besar kemakmuran rakyat.

2. Penguasaan hutan oleh Negara sebagaimana dimaksud pada ayat (1) memberi wewenang kepada pemerintah untuk:

a. mengatur dan mengurus segala sesuatu yang berkaitan dengan hutan, kawasan hutan, dan hasil hutan;

b. menetapkan status wilayah tertentu sebagai kawasan hutan atau kawasan hutan sebagai bukan kawasan hutan; dan

c. mengatur dan menetapkan hubungan-hubungan hukum antara orang dengan hutan, serta mengatur perbuatan-perbuatan hukum mengenai kehutanan.

Adapun Makna "dikuasai oleh negara" diatur secara tersurat dalam Pasal 10 Undang Undang Nomor 41 Tahun 1999 tentang Kehutanan, pengertian "dikuasai oleh negara" diartikan mencakup makna penguasaan oleh negara sebagai pengelolaan (beheersdaad) bidang pertanahan, penelitian dan pengembangan, pendidikan dan latihan, serta penyuluhan.

Sementara itu, di bidang pertambangan, Pasal 1 Undang Undang Nomor 11 Tahun 1967 tentang Ketentuan-ketentuan Pokok Pertambangan menegaskan bahwa segala bahan galian yang terdapat dalam wilayah hukum pertambangan Indonesia yang merupakan endapan-endapan alam sebagai karunia Tuhan yang Maha Esa, adalah kekayaan Nasional bangsa Indonesia dan oleh karenanya dikuasai dan dipergunakan oleh Negara untuk sebesar-besarnya kemakmuran rakyat.
Hak menguasai Negara dalam bidang pertambangan mengandung pengertian pengelolaan. Hal ini tercermin di dalam Pasal 4 Undang-Undang Nomor 4 Tahun 2009 dinyatakan bahwa:

1. Mineral dan batubara sebagai sumber daya alam yang tak terbarukan merupakan kekayaan nasional yang dikuasai oleh negara untuk sebesarbesar kesejahteraan rakyat.

2. Penguasaan mineral dan batubara oleh negara sebagaimana dimaksud pada ayat (1) diselenggarakan oleh Pemerintah dan/atau pemerintah daerah.

Adapun pengertian "dikuasai oleh negara" dalam bidang pertambangan dapat dilihat dalam Pasal 6 ayat (1) Undang-Undang Nomor 4 Tahun 2009 tentang Mineral dan Batu Bara yang mencakup makna penguasaan oleh negara sebagai pengaturan (regelendaad), yakni mengatur dan menyelenggarakan peruntukan, penggunaan, persediaan dan pemeliharaan bidang pertanahan, menentukan dan mengatur hubunganhubungan hukum antara orang-orang dengan tanah, menentukan dan mengatur hubunganhubungan hukum antara orang-orang dan perbuatan-perbuatan hukum yang mengenai tanah. Hal tersebut dimaksudkan untuk tujuan sebesar-besarnya kemakmuran rakyat.

Dalam bidang pengairan, Hak menguasai oleh Negara bidang pengairan memberi wewenang kepada Pemerintah untuk mengelola serta mengembangkan kemanfaatan air dan atau sumber-sumber air; Menyusun mengesahkan, dan atau memberi izin berdasarkan perencanaan dan perencanaan teknis tata pengaturan air dan tata pengairan; Mengatur, mengesahkan dan atau memberi izin peruntukan, penggunaan, 
penyediaan air, dan atau sumber-sumber air; menentukan dan mengatur perbuatanperbuatan hukum dan hubungan-hubungan hukum antara orang dan atau badan hukum dalam persoalan air dan atau sumbersumber air. Untuk itu, pelaksanaannya tetap menghormati hak yang dimiliki oleh masyarakat adat setempat, sepanjang tidak bertentangan dengan kepentingan Nasional.

Menurut Pasal 3 Undang Undang Nomor 11 Tahun 1974 tentang Pengairan, Hak menguasai Negara dalam pengairan berupa:

a. Mengelola serta mengembangkan kemanfaatan air dan atau sumbersumber air;

b. Menyusun mengesahkan, dan atau memberi izin berdasarkan perencanaan dan perencanaan teknis tata pengaturan air dan tata pengairan;

c. Mengatur, mengesahkan dan atau memberi izin peruntukan, penggunaan, penyediaan air, dan atau sumbersumber air;

d. Mengatur, mengesahkan dan atau memberi izin pengusahaan air, dan atau sumber-sumber air;

e. Menentukan dan mengatur perbuatanperbuatan hukum dan hubunganhubungan hukum antara orang dan atau badan hokum dalam persoalan air dan atau sumber-sumber air;

2. Makna Dikuasi Oleh Negara dalam Beberapa Putusan Mahkamah Konstitusi

1) Perihal Privatisasi Minyak dan Gas Bumi (Putusan MK Nomor 002/PUUI/2003)

Putusan MK yang menarik untuk dibahas pertama adalah putusan tentang pengujian materiil Undang-Undang Nomor 22 Tahun 2001 tentang Minyak dan Gas Bumi. Secara keseluruhan, pasal-pasal dalam undangundang a quo tidak dapat dipisahkan oleh karena landasan filosofi diadakannya undang-undang tersebut adalah untuk meliberalisasi sektor minyak dan gas bumi di Indonesia sehingga menurut Para Pemohon bertentangan dengan Pasal 33 ayat (2) dan (3) UUD 1945 yang perinciannya lebih lanjut oleh Pemohon dijelaskan dalam bagan dengan membandingkan antara Undang-Undang Nomor 44 Tahun 1960, Undang-Undang Nomor 8 Tahun 1971, dan Undang-Undang Nomor 22 Tahun 2001 (vide Permohonan hal. 37-41)

Selanjutnya, dalam menemukan pengertian dan/atau maksud dari suatu ketentuan yang terdapat dalam pasal-pasal UUD 1945 ternyata tidak cukup apabila hanya berpegang pada bunyi teks pasal yang bersangkutan dan hanya dengan menggunakan satu metode interpretasi tertentu. UUD 1945, sebagaimana halnya setiap konstitusi, adalah sebuah sistem norma dasar yang memberikan landasan konstitusional bagi pencapaian tujuan hidup berbangsa dan bernegara sebagaimana digariskan dalam Pembukaan UUD 1945. Sebagai suatu sistem, UUD 1945 adalah susunan kaidah-kaidah konstitusional yang menjabarkan Kemerdekaan Kebangsaan Indonesia, sebagaimana ditegaskan dalam Pembukaan UUD 1945 khususnya alinea keempat.

UUD 1945 sebagai sebuah sistem, memiliki konsekuensi bahwa penguasaan oleh negara dalam Pasal 33 UUD 1945 memiliki pengertian yang lebih tinggi atau lebih luas daripada pemilikan dalam konsepsi hukum perdata. Konsepsi penguasaan oleh negara merupakan konsepsi hukum publik yang berkaitan dengan prinsip kedaulatan rakyat yang dianut dalam UUD 1945, baik di bidang politik (demokrasi politik) maupun ekonomi (demokrasi 
ekonomi). Dalam paham kedaulatan rakyat itu, rakyatlah yang diakui sebagai sumber, pemilik, dan sekaligus pemegang kekuasaan tertinggi dalam kehidupan bernegara, sesuai dengan doktrin "dari rakyat, oleh rakyat, dan untuk rakyat". Dalam pengertian kekuasaan tertinggi tersebut tercakup pula pengertian pemilikan publik oleh rakyat secara kolektif. Bahwa bumi dan air dan kekayaan alam yang terkandung di dalam wilayah hukum negara pada hakikatnya adalah milik publik seluruh rakyat secara kolektif yang dimandatkan kepada negara untuk menguasainya guna dipergunakan bagi sebesar-besarnya kemakmuran bersama. Karena itu, Pasal 33 ayat (3) menentukan "bumi dan air dan kekayaan alam yang terkandung di dalamnya dikuasai oleh negara dan dipergunakan untuk sebesar-besar kemakmuran rakyat".

Sehingga, apabila pengertian "dikuasai oleh negara" hanya diartikan sebagai pemilikan dalam arti perdata (privat), maka hal dimaksud tidak mencukupi dalam menggunakan penguasaan itu untuk mencapai tujuan "sebesar-besarnya kemakmuran rakyat", yang dengan demikian berarti amanat untuk "memajukan kesejahteraan umum" dan "mewujudkan suatu keadilan sosial bagi seluruh rakyat Indonesia" dalam Pembukaan UUD 1945 tidak mungkin diwujudkan. Namun demikian, konsepsi kepemilikan perdata itu sendiri harus diakui sebagai salah satu konsekuensi logis penguasaan oleh negara yang mencakup juga pengertian kepemilikan publik oleh kolektivitas rakyat atas sumbersumber kekayaan dimaksud. Pengertian "dikuasai oleh negara" juga tidak dapat diartikan hanya sebatas sebagai hak untuk mengatur, karena hal demikian sudah dengan sendirinya melekat dalam fungsi-fungsi negara tanpa harus disebut secara khusus dalam undang-undang dasar.

Meskipun Pasal 33 tidak tercantum dalam UUD 1945, sebagaimana lazimnya di banyak negara yang menganut paham ekonomi liberal yang tidak mengatur norma-norma dasar perekonomian dalam konstitusinya, sudah dengan sendirinya negara berwenang melakukan fungsi pengaturan. Karena itu, pengertian "dikuasai oleh negara" tidak mungkin direduksi menjadi hanya kewenangan negara untuk mengatur perekonomian. Dengan demikian, baik pandangan yang mengartikan penguasaan oleh negara identik dengan pemilikan dalam konsepsi perdata maupun pandangan yang menafsirkan pengertian penguasaan oleh negara itu hanya sebatas kewenangan pengaturan oleh negara, keduanya ditolak oleh Mahkamah.

Berdasarkan uraian tersebut, pengertian "dikuasai oleh negara" harus diartikan mencakup makna penguasaan oleh negara dalam luas yang bersumber dan diturunkan dari konsepsi kedaulatan rakyat Indonesia atas segala sumber kekayaan "bumi, air dan kekayaan alam yang terkandung di dalamnya", termasuk juga di dalamnya pengertian kepemilikan publik oleh kolektivitas rakyat atas sumber-sumber kekayaan dimaksud. Rakyat secara kolektif itu dikonstruksikan oleh UUD 1945 memberikan mandat kepada negara untuk mengadakan kebijakan (beleid) dan tindakan pengurusan (bestuursdaad), pengaturan (regelendaad), pengelolaan (beheersdaad), dan pengawasan (toezichthoudensdaad) untuk tujuan sebesarbesarnya kemakmuran rakyat.

Fungsi pengurusan (bestuursdaad) oleh negara dilakukan oleh Pemerintah dengan kewenangannya untuk mengeluarkan dan 
mencabut fasilitas perijinan (vergunning), lisensi (licentie), dan konsesi (consessie). Fungsi pengaturan oleh negara (regelendaad) dilakukan melalui kewenangan legislasi oleh DPR bersama Pemerintah, dan regulasi oleh Pemerintah. Fungsi pengelolaan (beheersdaad) dilakukan melalui mekanisme pemilikan saham (share-holding) dan/ atau melalui keterlibatan langsung dalam manajemen Badan Usaha Milik Negara atau Badan Hukum Milik Negara sebagai instrumen kelembagaan, yang melaluinya Negara, c.q. Pemerintah, mendayagunakan penguasaannya atas sumber-sumber kekayaan itu untuk digunakan bagi sebesarbesarnya kemakmuran rakyat. Demikian juga fungsi pengawasan oleh negara (toezichthoudensdaad) dilakukan oleh Negara, c.q. Pemerintah, dalam rangka mengawasi dan mengendalikan agar pelaksanaan penguasaan oleh negara atas sumber-sumber kekayaan dimaksud benar-benar dilakukan untuk sebesar-besarnya kemakmuran seluruh rakyat.

Oleh karena itu, Mahkamah berpendapat, ketentuan Pasal 33 UUD 1945 tidaklah menolak privatisasi, asalkan privatisasi itu tidak meniadakan penguasaan Negara, c.q. Pemerintah, untuk menjadi penentu utama kebijakan usaha dalam cabang produksi yang penting bagi negara dan/atau menguasai orang banyak. Pasal 33 UUD 1945 juga tidak menolak ide kompetisi di antara para pelaku usaha, asalkan kompetisi itu tidak meniadakan penguasaan oleh negara yang mencakup kekuasaan untuk mengatur (regelendaad), mengurus (bestuursdaad), mengelola (beheersdaad), dan mengawasi (toezichthoudensdaad) cabang-cabang produksi yang penting bagi negara dan/atau menguasai hajat hidup orang banyak untuk tujuan sebesar-besarnya kemakmuran rakyat.

Berdasarkan pengertian "penguasaan oleh negara" yang telah menjadi pendirian Mahkamah dalam hubungannya dengan Pasal 33 UUD 1945 sebagaimana diuraikan di atas, ditambah dengan keterangan lisan dan tertulis Pemerintah maupun Dewan Perwakilan Rakyat serta pendapat para ahli, telah nyata bagi Mahkamah bahwa dalil-dalil yang diajukan oleh Para Pemohon tidak cukup beralasan, sehingga tidak terbukti pula undang-undang a quo secara keseluruhan bertentangan dengan UUD 1945. Karena substansi penguasaan oleh negara tampak cukup jelas dalam alur pikiran undang-undang a quo baik pada sektor hulu maupun hilir, kendatipun menurut Mahkamah masih ada hal-hal yang harus dipastikan jaminan penguasaan oleh negara tersebut sebagaimana nanti akan tampak dalam butir-butir pertimbangan Mahkamah atas pasal-pasal yang didalilkan Para Pemohon. Hal tersebut berbeda dengan Undang-undang Ketenagalistrikan yang telah diuji oleh Mahkamah dengan Putusan Perkara Nomor 001-021-022/PUU-I/2003 yang dibacakan pada tanggal 15 Desember 2004, yang alur pikir tentang prinsip penguasaan negara dimaksud tidak tampak dengan jelas penjabarannya dalam pasal-pasal Undang-undang Ketenagalistrikan tersebut yang seharusnya menjadi acuan pertama dan utama sesuai dengan amanat Pasal 33 UUD 1945. Perbedaan alur pikir dimaksud tercermin dalam konsiderans "Menimbang" kedua undang-undang yang bersangkutan, yang kemudian dijabarkan dalam pasal-pasal kedua undang-undang a quo. 


\section{2) Perihal Kewenangan Daerah di Bidang Pertanahan (Putusan MK Nomor 009/ PUU-I/2003)}

Perkara Nomor 009/PUU-I/2003 diajukan oleh ASPPAT Indonesia sebagai sebuah organisasi yang beranggotakan orangperorangan Pejabat Pembuat Akta Tanah. Berdasarkan ketentuan Pasal 51 ayat (1) Undang-undang Nomor 24 Tahun 2003 kedudukan Para Pemohon adalah sebagai perorangan warga negara Indonesia atau kelompok perorangan warga negara Indonesia. Permohonan Para Pemohon ini didasarkan pada adanya kekhawatiran Para Pemohon apabila Pasal 11 ayat (2) UU Nomor 22 Tahun 1999 akan dilaksanakan. Kekhawatiran tersebut didasarkan atas pendapat Para Pemohon bahwa:

(a) Dengan adanya Pasal 11 ayat (2) undang-undang a quo daerah akan mempunyai kewenangan yang luas di bidang pertanahan. Kewenangan yang luas tersebut menurut Para Pemohon dikhawatirkan akan menimbulkan akibat adanya pluralisme dalam hukum pertanahan di Indonesia, sehingga akan menghapuskan hukum tanah yang bersifat nasional;

(b) Hapusnya hukum tanah nasional yang digantikan oleh hukum tanah yang sifatnya kedaerahan akan bertentangan dengan Pasal 33 ayat (3) UUD 1945, karena menurut Para Pemohon penguasaan atas bumi, air dan kekayaan alam yang terkandung di dalamnya haruslah dilakukan oleh pemerintah pusat. Dengan diberikannya kewenangan yang luas kepada daerah dalam bidang pertanahan menurut Para Pemohon akan dapat menimbulkan disintegrasi Negara Kesatuan Republik Indonesia;

(c) Timbulnya kewenangan daerah yang sangat kuat dalam bidang pertanahan disebabkan oleh UU Nomor 22 Tahun 1999 memberikan urusan tersebut kepada daerah secara otonomi sebagaimana dimaksudkan oleh Pasal 11 ayat (2). Sesuai dengan asas negara kesatuan dan sesuai dengan semangat dan jiwa yang terkandung dalam UUD 1945, pemberian urusan pertanahan seharusnya tidak dengan cara pemberian otonomi melainkan dengan cara tugas pembantuan (medebewind), sehingga Pasal 11 ayat (2) bertentangan dengan jiwa dan semangat negara kesatuan sebagaimana terdapat dalam UUD 1945.

(d) Apabila terdapat pluralisme hukum tanah sebagai akibat Pasal 11 ayat (2) UU Nomor 22 Tahun 1999, maka Pejabat Pembuat Akta Tanah sebagai pejabat yang diangkat oleh Pemerintah Pusat akan sangat dirugikan karena Pemerintah Daerah dapat membuat peraturan daerahnya sendiri.

Di samping menyampaikan dasar-dasar kekhawatirannya apabila Pasal 11 ayat (2) UU Nomor 22 Tahun 1999 dilaksanakan, Para Pemohon juga menyampaikan fakta yang mempunyai kaitan dengan Pasal 11 ayat (2) UU a quo sebagai berikut:

(a) Bahwa hingga saat ini Pasal 11 ayat (2) UU Nomor 22 Tahun 1999 belum dilaksanakan oleh pemerintah sesuai dengan ketentuan Pasal 8 ayat (1) UU No. 22 Tahun 1999 yakni Pemerintah Pusat harus menyerahkan atau mengalihkan pembiayaan, personalia, peralatan dan dokumen sepanjang mengenai 
pertanahan kepada Pemerintah Daerah. Pemerintah Pusat dalam hal ini Presiden telah menerbitkan Keputusan Presiden No. 10 Tahun 2001 tentang Pelaksanaan Otonomi Daerah di Bidang Pertanahan, pada tanggal 7 Januari 2001 yang isinya menyatakan bahwa peraturan, keputusan, instruksi, dan Surat Edaran Menteri Negara Agraria/Kepala Badan Pertanahan Nasional yang telah ada masih berlaku sebelum ditetapkan peraturan yang baru berdasarkan Peraturan Pemerintah No. 25 Tahun 2000.

(b) Bahwa Menteri Dalam Negeri pada tanggal 23 Januari 2001 mengirim surat kepada Gubernur dan Bupati/Walikota seluruh Indonesia yang intinya menyatakan bahwa Keputusan Presiden No 10 Tahun 2001 dimaksudkan untuk menciptakan unifikasi peraturan pertanahan, sehingga tidak diperkenankan bagi daerah untuk menerbitkan Peraturan Daerah dan Keputusan Kepala Daerah mengenai pertanahan yang bertentangan dengan peraturan yang ada. Kewenangan di bidang pertanahan khususnya berkaitan dengan aspek hukum pertanahan, bagi terwujudnya unifikasi hukum pertanahan dan kepastian hukum di bidang pertanahan, tetap menjadi wewenang Pemerintah Pusat.

(c) Bahwa Presiden telah menerbitkan Keputusan Presiden Republik Indonesia Nomor 34 Tahun 2003 tentang Kebijakan Nasional di Bidang Pertanahan. Dalam Pasal 2 KEPPRES ini dinyatakan bahwa sebagian kewenangan di bidang pertanahan dilaksanakan oleh Pemerintah Kabupaten/Kota yang meliputi : (a) pemberian ijin lokasi, (b) penyelenggaraan pengadaan tanah untuk kepentingan pembangunan, (c) penyelesaian sengketa tanah garapan, (d) penyelesaian masalah ganti kerugian dan santunan tanah untuk pembangunan, (e) penetapan subyek dan obyek redistribusi tanah, serta ganti kerugian tanah kelebihan maksimum dan tanah absentee, (f) penetapan dan penyelesaian masalah tanah ulayat; (g) pemanfaatan dan penyelesaian masalah tanah kosong, (h) pemberian ijin membuka tanah (i) perencanaa penggunaan tanah wilayah Kabupaten/Kota.

(d) Bahwa Departemen Dalam Negeri telah menyusun naskah Rancangan UndangUndang tentang Pemerintah Daerah yang dimaksud sebagai penyempurnaan terhadap UU No 22 Tahun 1999. Dalam naskah yang disusun oleh Departeman Dalam Negeri tersebut untuk masalah tanah telah diminta pendapat Kepala Badan Pertanahan Nasional. Pendapat Kepala Badan Pertanahan Nasional atas permintaan pendapat tersebut menyarankan agar bidang pertanahan tidak termasuk dalam urusan yang diserahkan kepada daerah.

Dengan mempertimbangkan hal-hal sebagaimana tersebut di atas serta praktik yang berlangsung selama ini terbukti Pasal 11 ayat (2) UU No.22 Tahun 1999 tidak menimbulkan pengaruh langsung kepada Para Pemohon, karena tidak terjadi perubahan sama sekali dalam hukum pertanahan khususnya yang berkaitan dengan kepentingan Para Pemohon sebagai Pejabat Pembuat Akta Tanah.

Menariknya, Para Pemohon ternyata tidak dirugikan kepentingannya hingga saat ini, dan dengan demikian kekhawatiran Para 
Pemohon terlalu dini (premature), apalagi UU Nomor 22 Tahun 1999 akan dilakukan perubahan, termasuk di dalamnya Pasal 11 ayat (2). Dalam kaitan ini, Mahkamah Konstitusi menilai bahwa materi permohonan Para Pemohon layak mendapat perhatian yang sungguh-sungguh dari pembuat undangundang dalam penyempurnaan UU Nomor 22 Tahun 1999. Selanjutnya, berdasarkan pertimbangan-pertimbangan tersebut di atas Mahkamah Konstitusi berpendapat kepentingan Para Pemohon tidak dirugikan oleh Pasal 11 ayat (2) UU Nomor 22 Tahun 1999, karena permohonan Para Pemohon hanya didasarkan atas kekhawatiran yang masih premature.

\section{3) Putusan Pasal 22 UU Nomor 25 Tahun 2008 tentang Penanaman Modal (Perkara Nomor 21-22/PUU-V/2007}

Dalam perkara pengujian Undang-Undang Nomor 25 tahun 2007 tentang Penanaman Modal khususnya Pasal 22, telah pula ditunjukkan pendirian Mahkamah bahwa ketentuan masa berlakunya Hak Guna Usaha, Hak Guna Bangunan, Hak Pakai telah melanggar wewenang negara sehingga masa berlakunya hak-hak tersebut dibatalkan oleh Mahkamah.

Pasal 22 undang-undang a quo mengatur tentang hak-hak atas tanah. Sedangkan tanah jelas merupakan objek yang tunduk pada ketentuan Pasal 33 ayat (3) UUD 1945 sehingga melekat hak penguasaan oleh negara di dalamnya. Pada saat yang sama, UU Penanaman Modal adalah bagian dari pembangunanekonominasional, sebagaimana tampak jelas dari konsiderans, pasal-pasal, maupun penjelasannya. Menurut Pasal 33 ayat (4) UUD 1945, perekonomian nasional diselenggarakan berdasar atas demokrasi ekonomi dengan prinsip kebersamaan, efisiensi berkeadilan, berwawasan lingkungan, kemandirian, serta menjaga keseimbangan kemajuan dan kesatuan ekonomi nasional. Dengan demikian, masalah yang selanjutnya harus dipertimbangkan oleh Mahkamah dalam menguji konstitusionalitas Pasal 22, khususnya ayat (1) dan ayat (2) UU Penanaman Modal adalah:

a) apakah pemberian hak-hak atas tanah yang dapat diperpanjang di muka sekaligus sebagai fasilitas kepada perusahaan penanaman modal, sebagaimana dirumuskan dalam Pasal 22 Ayat (1) dan Ayat (2) bertentangan dengan pengertian "dikuasai oleh negara", sebagaimana dimaksud Pasal 33 Ayat (3) UUD 1945;

b) apakah pemberian hak-hak atas tanah yang dapat diperpanjang di muka sekaligus sebagai fasilitas kepada perusahaan penanaman modal, sebagaimana dirumuskan dalam Pasal 22 Ayat (1) dan Ayat (2) bertentangan dengan demokrasi ekonomi, sebagaimana dimaksud Pasal 33 Ayat (4) UUD 1945.

Terhadap kedua permasalahan tersebut, Mahkamah berpendapat sebagai berikut: Mahkamah berpendapat, dari rumusan Pasal 22 UU Penanaman Modal di atas tampak bahwa ketentuan dalam Pasal 22 ayat (1) huruf $a, b$, dan $c$ adalah dimaksudkan sebagai pemberian kemudahan dan/atau pelayanan perizinan kepada perusahaan penanaman modal untuk memperoleh hak atas tanah. Bentuk pelayanan tersebut berupa pemberian dan perpanjangan di muka sekaligus untuk hak atas tanah yang dimohonkan (hak guna usaha, hak guna bangunan, dan hak pakai). 
Hak guna usaha (HGU) dapat diberikan dan diperpanjang di muka sekaligus selama 60 (enam puluh) tahun, hak guna bangunan (HGB) dapat diberikan dan diperpanjang di muka sekaligus selama 50 (lima puluh) tahun, dan hak pakai dapat diberikan dan diperpanjang di muka sekaligus selama 40 (empat puluh) tahun. Sementara itu, dalam Penjelasan Umum UU Penanaman Modal dikatakan bahwa penyelenggaraan penanaman modal hanya dapat tercapai apabila faktor penunjang yang menghambat iklim penanaman modal dapat diatasi, antara lain, melalui perbaikan koordinasi antarinstansi Pemerintah Pusat dan Pemerintah Daerah, penciptaan birokrasi yang efisien, kepastian hukum di bidang penanaman modal, biaya ekonomi yang berdaya saing tinggi, serta iklim usaha yang kondusif di bidang ketenagakerjaan dan keamanan berusaha. Dengan kata lain, apabila dikelompokkan, maka faktorfaktor yang menghambat iklim penanaman modal tersebut adalah (i) persoalan good governance; (ii) persoalan kepastian hukum dan keamanan berusaha; dan (iii) persoalan ketenagakerjaan.

Dengan uraian demikian, Mahkamah tidak menemukan adanya korelasi langsung antara fasilitas atau insentif berupa pemberian hakhak atas tanah (in casu HGU, HGB, dan Hak Pakai) yang dapat diperpanjang di muka sekaligus, sebagaimana dirumuskan dalam Pasal 22 ayat (1) dan ayat (2) UU Penanaman Modal, dengan peningkatan iklim penanaman modal apabila persoalan good governance, kepastian hukum dan keamanan berusaha, serta persoalan ketenagakerjaan tidak mengalami perbaikan. Dengan kata lain, masalah utama dalam menciptakan iklim investasi yang kondusif adalah terletak pada persoalan good governance, kepastian hukum dan keamanan berusaha, serta persoalan ketenagakerjaan.

Pertanyaannya kemudian, apakah karena alasan bahwa tanah merupakan objek yang tunduk pada prinsip penguasaan oleh negara dan bahwa ternyata pemberian fasilitas berupa pemberian HGU, HGB, dan Hak Pakai kepada perusahaan penanaman modal tidak berkaitan langsung dengan peningkatan iklim yang kondusif bagi penanaman modal secara serta-merta mengakibatkan pemberian fasilitas demikian kepada perusahaan penanaman modal berarti bertentangan dengan prinsip penguasaan oleh negara sebagaimana dimaksud oleh Pasal 33 ayat (3) UUD 1945.

Terhadap pertanyaan ini Mahkamah berpendapat bahwa pemberian fasilitas berupa hak-hak atas tanah demikian an sich tidaklah bertentangan dengan prinsip penguasaan oleh negara dengan alasan:

1) Pertama, bahwa dalam rumusan Pasal 33 Ayat (3) UUD 1945 terdapat kepentingan yang dilindungi oleh konstitusi dan karena itu penting ditegaskan adanya penguasaan oleh negara. Kepentingan yang hendak dilindungi oleh konstitusi adalah kemakmuran rakyat dalam kaitannya dengan pemanfaatan bumi, air, kekayaan yang terkandung di dalamnya. Oleh karena itu, sepanjang menyangkut tanah, maka atas dasar adanya kepentingan yang dilindungi oleh konstitusi itulah dibuat kebijakan nasional di bidang pertanahan yang dimaksudkan untuk mencapai tujuan kemakmuran rakyat, di antaranya berupa pendistribusian kembali pemilikan atas tanah dan pembatasan pemilikan luas tanah pertanian, sehingga penguasaan 
atau pemilikan tanah tidak terpusat pada sekelompok orang tertentu. Inilah yang antara lain dilakukan melalui UU 5/1960 16 dan UU 56Prp/1960 17 , dengan adanya pembatasan dan pendistribusian demikian berarti sumber ekonomi akan tersebar pula secara lebih merata dan pada akhirnya akan tercapai tujuan pemerataan kemakmuran rakyat;

2) Kedua, pemberian fasilitas $\mathrm{HGU}, \mathrm{HGB}$, dan Hak Pakai demikian tidak meniadakan atau mengurangi kewenangan negara untuk menjalankan mandatnya yang diberikan oleh rakyat secara kolektif untuk melakukan tindakan pengurusan (bestuursdaad), pengaturan (regelendaad), pengelolaan (beheersdaad), dan pengawasan (toezichthoudensdaad);

3) Ketiga, tanpa bermaksud menguji pemberian hak-hak atas tanah dalam undang-undang a quo dengan pemberian hak-hak yang sama dalam undang-undang lain, seperti Undang-Undang Nomor 5 Tahun 1960 tentang Peraturan Dasar Pokok-pokok Agraria (UUPA) dan UndangUndang Nomor 18 Tahun 2004 tentang Perkebunan, fakta bahwa hak-hak atas tanah demikian telah pernah diberikan sebelumnya dalam rangka penanaman modal ipso facto merupakan bukti adanya penerimaan masyarakat (social acceptance).

Namun, yang menjadi masalah adalah ketika pemberian hak-hak atas tanah demikian (HGU, HGB, dan Hak Pakai) diberikan dengan perpanjangan di muka sekaligus, apakah tidak justru meniadakan atau mengurangi kewenangan negara untuk melakukan tindakan pengurusan (bestuursdaad), pengaturan (regelendaad), pengelolaan (beheersdaad), dan pengawasan (toezichthoudensdaad). Terhadap pertanyaan ini Mahkamah berpendapat bahwa hal demikian dapat mengurangi, sekalipun tidak meniadakan, prinsip penguasaan oleh negara, dalam hal ini berkenaan dengan kewenangan negara untuk melakukan tindakan pengawasan (toezichthoudensdaad) dan pengelolaan (beheersdaad). Alasannya, karena meskipun terdapat ketentuan yang memungkinkan negara, in casu Pemerintah, untuk menghentikan atau membatalkan hak-hak atas tanah dimaksud dengan alasanalasan sebagaimana ditentukan dalam Pasal 22 ayat (4) UU Penanaman Modal, namun oleh karena hak-hak atas tanah dimaksud dinyatakan dapat diperpanjang di muka sekaligus, sebagaimana ditentukan dalam Pasal 22 ayat (1) dan ayat (2), kewenangan kontrol oleh negara untuk melakukan tindakan pengawasan (toezichthoudensdaad) maupun pengelolaan (beheersdaad) menjadi berkurang atau bahkan terhalang sebab:

1) kewenangan negara yang terdapat dalam Pasal 22 ayat (4) UU Penanaman Modal tersebut bersifat sangat eksepsional dan terbatas. Dikatakan eksepsional dan terbatas karena negara tidak boleh menghentikan atau membatalkan hak-

\footnotetext{
16 Undang-Undang Nomor 5 Tahun 1960 tentang Peraturan Dasar Pokok-Pokok Agraria (UUPA) (Lembaran Negara Republik Indonesia Tahun 1960 Nomor 104, Tambahan Lembaran Negara Republik Indonesia Nomor 2043).

17 Undang-Undang Nomor 56 Prp Tahun 1960 tentang Pembatasan Luas Tanah Pertanian (Lembaran Negara Republik Indonesia Tahun 2004 Nomor 116, Tambahan Lembaran Negara Republik Indonesia Nomor 4431).
} 
hak atas tanah tersebut di luar alasanalasan yang secara terbatas (limitatif) telah ditentukan dalam Pasal 22 ayat (4) UU Penanaman Modal. Dengan kata lain, negara tidak lagi bebas menjalankan kehendaknya untuk menghentikan atau tidak memperpanjang hak-hak atas tanah sebagaimana jika perpanjangan hak-hak atas tanah itu tidak diberikan secara di muka sekaligus;

2) karena pemberian dan perpanjangan hak-hak atas tanah tersebut diberikan sekaligus di muka, maka ketika negara menghentikan atau membatalkan perpanjangan hak-hak atas tanah dimaksud, meskipun telah didasarkan atas alasan sebagaimana ditentukan dalam Pasal 22 ayat (4) UU Penanaman Modal, perusahaan penanaman modal tetap berhak mempersoalkan keabsahan tindakan negara tersebut. Keadaan demikian sudah tentu tidak akan terjadi jika perpanjangan hak-hak atas tanah itu tidak diberikan secara sekaligus di muka. Karena, apakah pemberian hak-hak atas tanah itu akan diperpanjang atau tidak jika jangka waktunya telah habis, hal itu sepenuhnya merupakan kewenangan negara. Dengan kata lain, perpanjangan hak atas tanah yang diberikan sekaligus di muka memperlemah posisi negara dalam menguasai hak atas tanah sebagaimana dimaksud Pasal 33 ayat (3) UUD 1945;

3) karena pemberian dan perpanjangan hakhak atas tanah yang diberikan sekaligus di muka tersebut juga menghambat negara untuk melakukan pemerataan kesempatan untuk memperoleh hak-hak atas tanah tersebut secara adil. Misalnya, tatkala negara hendak mengalihkan hak- hak atas tanah tersebut kepada pihak lain setelah jangka waktu hak-hak atas tanah itu habis, hal itu menjadi tidak mungkin dilakukan karena antara pemberian hak dan perpanjangan diberikan sekaligus di muka. Sementara itu, dalam Pasal 22 ayat (4) UU Penanaman Modal, alasan pemerataan kesempatan tersebut di atas tidak termasuk salah satu alasan yang dapat digunakan oleh negara untuk menghentikan atau membatalkan hak-hak atas tanah. Dengan demikian, karena adanya ketentuan bahwa HGU, HGB, dan Hak Pakai dapat diberikan dan diperpanjang sekaligus di muka tersebut sebagian dari kewenangan negara untuk melakukan tindakan pengelolaan (beheersdaad), dalam hal ini kewenangan untuk melakukan pemerataan kesempatan untuk mendapatkan hak-hak atas tanah secara lebih adil dan lebih merata, menjadi terhalang. Pada saat yang sama, keadaan demikian menyebabkan negara terhalang pula untuk melakukan kewajibannya melaksanakan perintah Pasal 33 Ayat (3) UUD 1945, yaitu pemerataan kesempatan untuk menjaga kepentingan yang dilindungi konstitusi sebagaimana telah diuraikan di atas.

Selanjutnya, berkenaan dengan pertanyaan huruf b), yaitu apakah pemberian hak-hak atas tanah yang dapat diperpanjang di muka sekaligus tersebut bertentangan dengan demokrasi ekonomi, sebagaimana dimaksud Pasal 33 ayat (4) UUD 1945. Oleh karena pemberian hak-hak atas tanah, baik HGU, HGB, maupun Hak Pakai, an sich menurut Mahkamah telah dinyatakan tidak bertentangan dengan Pasal 33 UUD 1945, maka 
masalahnya sekarang, apakah pemberian hak-hak atas tanah demikian yang dapat diperpanjang di muka sekaligus bertentangan dengan demokrasi ekonomi, sebagaimana dimaksud oleh Pasal 33 Ayat (4) UUD 1945. Sebelum mempertimbangkan lebih jauh akan hal ini, tentang makna demokrasi ekonomi telah diuraikan dalam pertimbangan paragraf [3.21] putusan ini, yaitu kedaulatan rakyat di bidang ekonomi, sehingga pertanyaannya kemudian adalah apakah pemberian HGU, HGB, dan Hak Pakai yang dapat diperpanjang di muka sekaligus tersebut bertentangan dengan kedaulatan rakyat di bidang ekonomi.

Terhadap permasalahan tersebut Mahkamah berpendapat, sebagaimana telah diuraikan dalam pertimbangan terhadap permasalahan padahurufa) diatas yaitu bahwa meskipun terhadap HGU, HGB, dan Hak Pakai yang dapat diperpanjang di muka sekaligus itu negara dikatakan dapat menghentikan atau membatalkan sewaktu-waktu, namun alasan penghentian atau pembatalan tersebut telah ditentukan secara limitatif dalam Pasal 22 Ayat (4) UU Penanaman Modal. Dengan demikian, di satu pihak, kewenangan negara untuk menghentikan atau tidak memperpanjang HGU, HGB, dan Hak Pakai tersebut tidak lagi dapat dilakukan atas dasar kehendak bebas negara karena terikat pada alasan limitatif yang ditentukan dalam Pasal 22 Ayat (4) UU Penanaman Modal, di lain pihak, perusahaan penanaman modal dapat mempersoalkan secara hukum keabsahan tindakan penghentian atau pembatalan hak atas tanah itu.

Dari perspektif demikian, pemberian perpanjangan hak-hak atas tanah sekaligus di muka tersebut telah mengurangi dan bahkan melemahkan kedaulatan rakyat di bidang ekonomi. Sebab, kewenangan untuk menghentikan atau tidak memperpanjang perpanjangan hak-hak atas tanah yang - jika tidak terdapat kata-kata "dapat diperpanjang sekaligus di muka" - sepenuhnya merupakan keputusan yang lahir dari kehendak bebas negara. Namun, setelah hak-hak atas tanah tersebut dinyatakan "dapat diperpanjang sekaligus di muka", maka wewenang negara untuk menghentikan atau tidak memperpanjang hak-hak atas tanah dimaksud tidak lagi merupakan keputusan yang sepenuhnya lahir dari kehendak bebas negara. Demikian pula, karena adanya limitasi dalam alasan penghentian atau pembatalan hak-hak atas tanah yang "dapat diperpanjang di muka sekaligus" tersebut, kewenangan negara untuk menghentikan atau membatalkan hakhak atas tanah dimaksud menjadi terbuka untuk dipersoalkan secara hukum oleh perusahaan penanaman modal, hal mana tidak akan terjadi jika tidak ada kata-kata "dapat diperpanjang di muka sekaligus".

Berkurang atau melemahnya kedaulatan rakyat di bidang ekonomi sebagai akibat dari adanya kata-kata "dapat diperpanjang di muka sekaligus" makin jelas jika dihubungkan dengan ketentuan tentang penyelesaian sengketa sebagaimana diatur dalam Pasal 32 UU Penanaman Modal yang selengkapnya berbunyi sebagai berikut:

(1) Dalam hal terjadi sengketa di bidang penanaman modal antara Pemerintah dengan penanam modal, para pihak terlebih dahulu menyelesaikan sengketa tersebut melalui musyawarah mufakat.

(2) Dalam hal penyelesaian sengketa sebagaimana dimaksud pada Ayat (1) tidak tercapai, penyelesaian sengketa tersebut dilakukan melalui arbitrase atau alternatif penyelesaian sengketa atau pengadilan sesuai dengan 
ketentuan peraturan perundangundangan.

(3) Dalam hal terjadi sengketa di bidang penanaman modal antara Pemerintah dengan penanam modal dalam negeri, para pihak dapat menyelesaikan sengketa tersebut melalui arbitrase berdasarkan kesepakatan para pihak, dan jika penyelesaian sengketa melalui arbitrase tidak disepakati, penyelesaian sengketa tersebut akan dilakukan di pengadilan.

(4) Dalam hal terjadi sengketa di bidang penanaman modal antara Pemerintah dengan penanam modal asing, para pihak akan menyelesaikan sengketa tersebut melalui arbitrase internasional yang harus disepakati oleh para pihak.

Terjadinya pengurangan atau pelemahan kedaulatan rakyat di bidang ekonomi yang diakibatkan oleh adanya ketentuan bahwa hak-hak atas tanah (HGU, HGB, dan Hak Pakai) "dapat diperpanjang di muka sekaligus" itu dalam kaitannya dengan ketentuan dalam Pasal 32 UU Penanaman Modal tersebut dapat dijelaskan sebagai berikut:

a) Apabila negara, c.q. Pemerintah, menghentikan atau membatalkan hakhak atas tanah (HGU, HGB, dan Hak Pakai) yang "dapat diperpanjang di muka sekaligus" itu di mana kemudian tindakan itu dipersoalkan secara hukum oleh pihak penanam modal maka berarti telah terjadi sengketa penanaman modal antara Pemerintah dan penanam modal. Dengan demikian maka berlaku ketentuan sebagaimana diatur dalam Pasal 32 UU Penanaman Modal di atas;

b) Pemerintah, menurut Pasal 1 angka 12 UU Penanaman Modal adalah "Presiden Republik Indonesia yang memegang kekuasaan pemerintahan negara Republik Indonesia sebagaimana dimaksud dalam Undang-Undang Dasar Negara Republik Indonesia Tahun 1945". Artinya, tatkala Pemerintah melakukan tindakan penghentian atau pembatalan hak atas tanah tersebut ia adalah bertindak atas nama negara dalam kualifikasi de jure empirii (pemegang kedaulatan), sehingga apabila keabsahan tindakannya diragukan maka pengadilan dalam lingkungan peradilan tata usaha negaralah yang mempunyai kompetensi absolut untuk mengadilinya. Karena hubungan antara negara, c.q. Pemerintah, dan penanam modal dalam konteks pemberian dan perpanjangan HGU, HGB, dan Hak Pakai tersebut adalah hubungan antara pemberi izin dan penerima izin, bukan hubungan kontraktual;

c) Namun ternyata, tindakan negara yang sesungguhnya dilakukan dalam kualifikasi sebagai de jure empirii tersebut, terutama oleh Pasal 32 Ayat (4) UU Penanaman Modal, akan "diadili" oleh arbitrase internasional. Arbitrase adalah sarana penyelesaian sengketa antar pihak-pihak yang sederajat. Berarti, dengan kata lain, tindakan negara tersebut oleh Pasal 32 Ayat (4) UU Penanaman Modal secara implisit dikualifikasikan sebagai tindakan subjek hukum perdata biasa (de jure gestiones) yang kedudukannya sederajat dengan penanam modal. Seharusnya klausul penyelesaian sengketa melalui arbitrase dicantumkan dalam rumusan kontrak, kasus demi kasus, bukan dalam perumusan undang-undang yang berlaku umum dan bersifat permanen yang justru mempersulit Pemerintah sendiri. Lagi pula, rumusan dalam Pasal 32 Ayat (4) UU Penanaman Modal memperlihatkan 


\section{R Ruenal HTS VINDING}

Media Pembinaan Hukum Nasional

indikasi ketidakpercayaan terhadap institusi peradilan di Indonesia yang dilegalisasikan secara permanen oleh pembentuk undang-undang. Hal demikian juga berarti mengurangi makna kedaulatan hukum Negara Kesatuan Republik Indonesia berdasarkan UUD 1945.

Dengan uraian pada huruf a) sampai dengan c) di atas, maka telah nyata bagi Mahkamah bahwa pemberian hak-hak atas tanah yang "dapat diperpanjang di muka sekaligus" dalam rumusan Pasal 22 Ayat (1) dan Ayat (2) maupun kata-kata "sekaligus di muka" dalam Pasal 22 Ayat (4) UU Penanaman Modal telah mengurangi, memperlemah, atau bahkan dalam keadaan tertentu menghilangkan kedaulatan rakyat di bidang ekonomi. Dengan demikian, dalam menilai konstitusionalitas Pasal 22 UU Penanaman Modal di atas, baik dilihat dari sudut pandang prinsip penguasaan oleh negara, yang di dalamnya termasuk perlindungan terhadap kepentingan yang dilindungi oleh konstitusi, maupun dari sudut pandang kedaulatan rakyat di bidang ekonomi, sebagaimana terkandung dalam pengertian Pasal 33 UUD 1945, telah ternyata bahwa pemberian hak-hak atas tanah kepada perusahaan penanaman modal baik HGU, HGB, maupun Hak Pakai yang dapat diperpanjang di muka sekaligus, sebagaimana diatur dalam Pasal 22 UU Penanaman Modal, bertentangan dengan prinsip penguasaan oleh negara maupun kedaulatan rakyat di bidang ekonomi sebagaimana dimaksud oleh Pasal 33 UUD 1945.

Dengan dinyatakannya Pasal 22 UU Penanaman Modal bertentangan dengan Pasal 33 UUD 1945, sementara Pasal 22 UU Penanaman Modal tersebut merujuk pada
Volume 8 Nomor 3, Desember 2019

dan berkait dengan Pasal 21 huruf a UU Penanaman Modal, maka sesuai dengan pendirian Mahkamah terhadap Pasal 39 UU Penanaman Modal sebagaimana telah diuraikan di atas, ketentuan yang berlaku terhadap pemberian kemudahan dan/atau pelayanan kepada perusahaan penanaman modal untuk memperoleh hak atas tanah adalah ketentuan yang terdapat dalam peraturan perundang-undangan lainnya sepanjang berkaitan langsung dengan penanaman modal. Khusus mengenai pemberian, perpanjangan, dan pembaruan hak-hak atas tanah (HGU, HGB, dan Hak Pakai) berlaku ketentuan Undang-Undang Nomor 5 Tahun 1960 tentang Peraturan Dasar Pokokpokok Agraria (Lembaran Negara Republik Indonesia Nomor 104 Tahun 1960, Tambahan Lembaran Negara Republik Indonesia Nomor 2043) dan Peraturan Pemerintah Nomor 40 Tahun 1996 tentang Hak Guna Usaha, Hak Guna Bangunan, dan Hak Pakai Atas Tanah.

Atas dasar pertimbangan tersebut di atas Mahkamah Menyatakan bahwa Pasal 22 Ayat (1), ayat (2) dan ayat (4) Undang-Undang Nomor 25 Tahun 2007 tentang Penanaman Modal (Lembaran Negara Republik Indonesia Tahun 2007 Nomor 67, Tambahan Lembaran Negara Republik Indonesia Nomor 4724) tidak mempunyai kekuatan hukum mengikat, sehingga Pasal 22 Undang-Undang Nomor 25 Tahun 2007 dimaksud menjadi berbunyi:

(1) Kemudahan pelayanan dan/atau perizinan hak atas tanah sebagaimana dimaksud dalam Pasal 21 huruf a dapat diberikan dan diperpanjang dan dapat diperbarui kembali atas permohonan penanam modal.

(2) Hak atas tanah sebagaimana dimaksud pada Ayat (1) dapat diberikan dan 
diperpanjang untuk kegiatan penanaman modal, dengan persyaratan antara lain:

a. penanaman modal yang dilakukan dalam jangka panjang dan terkait dengan perubahan struktur perekonomian Indonesia yang lebih berdaya saing;

b. penanaman modal dengan tingkat risiko penanaman modal yang memerlukan pengembalian modal dalam jangka panjang sesuai dengan jenis kegiatan penanaman modal yang dilakukan;

c. penanaman modal yang tidak memerlukan area yang luas;

d. penanaman modal dengan menggunakan hak atas tanah negara; dan

e. penanaman modal yang tidak mengganggu rasa keadilan masyarakat dan tidak merugikan kepentingan umum.

(3) Hak atas tanah dapat diperbarui setelah dilakukan evaluasi bahwa tanahnya masih digunakan dan diusahakan dengan baik sesuai dengan keadaan, sifat, dan tujuan pemberian hak.

(4) Pemberian dan perpanjangan hak atas tanah yang diberikan dan yang dapat diperbarui sebagaimana dimaksud pada ayat (1) dan ayat (2) dapat dihentikan atau dibatalkan oleh Pemerintah jika perusahaan penanaman modal menelantarkan tanah, merugikan kepentingan umum, menggunakan atau memanfaatkan tanah tidak sesuai dengan maksud dan tujuan pemberian hak atas tanahnya, serta melanggar ketentuan peraturan perundang-undangan di bidang pertanahan.

\section{Penutup}

Berdasarkan uraian tersebut di atas maka dapat disimpulkan bahwa hak menguasai negara khususnya dibidang pertanahan merupakan hak yang diberikan kepada negara untuk pengurusan (bestuursdaad), pengaturan (regelendaad), pengelolaan (beheersdaad), dan pengawasan (toezichthoudensdaad) untuk tujuan sebesar-besarnya kemakmuran rakyat. Sebagai salah satu lembaga kekuasan kehakiman Mahkamah Konstitusi memiliki peranan dalam memberikan kontribusi pembaharuan hukum agraria (dalam arti luas), yang dituangkan melalui putusanputusan tentang pengujian Undang-Undang terhadap Undang-Udang Dasar 1945. Putusan Mahkamah juga sekaligus menutup lubanglubang kekurangan atau ketidakjelasan Undang-Undang. Upaya ini masih dalam lingkup kewenangan konstitusi, agar dengan demikian segera terwujud suatu tatanan di bidang hukum agraria yang terpadu, koheren dan menjamin kepastian hukum dan menjamin terciptanya keadilan sesuai dengan konstitusi.

\section{Daftar Pustaka}

\section{Buku}

Bakri, Muhammad, Hak Menguasai Tanah oleh Negara: Paradigma Baru untuk reformasi Agraria, cetakan 1 (Yoyakarta: Citra Media, 2007)

Erwiningsih, Winahyu, "Pelaksanaan Pengaturan Hak Menguasai Tanah Negara atas Tanah Menurut UUD 1945", Jurnal Hukum Edisi Khusus Volume 16, Oktober 2009.

Halim, Ridwan, Hukum Agraria dalam Tanya Jawab, (Jakarta: Ghalia Indonesia)

Harsono, Budi, Hukum Agraria Indonesia, Sejarah Pembentukan Undang-undang Pokok Agraria Isi Dan Pelaksanaannya, (Jakarta: Penerbit Djambatan, 1995)

Hatta, Mohammad, Penjabaran Pasal 33 UndangUndang Dasar 1945, (Jakarta: Mutiara, 1977)

Marzuki, Peter Mahmud, Penelitian Hukum (Jakarta: Kencana Media Group, 2014) 
Soetikno, Iman, Politik Agraia Nasional, (Yogyakarta: Gadjah Mada Univcersity press, cetakan ketiga,1990)

Sumardjono, Maria, dkk., Pengaturan Sumber Daya Alam di Indonesia, Antara yang Tersurat dan Tersirat, (Yogyakarta: Gadjah Mada University Press, 2011).

\section{Makalah/Jurnal/ Artikel/Hasil Seminar}

Arizona, Yance, "Perkembangan Konstitusionalitas Penguasaan Negara Atas Sumber Daya Alam dalam Putusan Mahkamah Konstitusi", Jurnal Konstitusi, Vol. 8, No. 3, Juni 2011.

Nugroho, Okky Chahyo, "Konflik Agraria di Maluku di Tinjau Dari Perspektif Hak Asasi Manusia", Jurnal HAM Volume 9 (1) Juni 2018.

Posner, Richard. A., Frontiers of Legal Theory (Cambridge-Masschusetts-London-England: Harvard University Press)
Sodiki, Achmad, "Kebijakan Sumber Daya Alam dan Implikasi Yuridisnya Pasca Ketetapan MPR Nomor IX Tahun 2001 dan KepPres Nomor 34 Tahun 2003", Makalah disampaikan pada Seminar Nasional "Eksistensi Kewenangan BPN Pasca Keppres Nomor 34 Tahun 2003", Malang.

Putusan Mahkamah Konstitusi Nomor 21-22/ PUU-V/2007 perihal Pengujian UndangUndang Nomor 25 Tahun 2008 tentang Penanaman Modal.

Putusan Mahkamah Konstitusi Nomor 002/PUUI/2003 perihal Pengujian Undang-Undang Nomor 22 Tahun 2001 tentang Minyak dan Gas Bumi.

Putusan Mahkamah Konstitusi Nomor 009/ PUU-1/2003 perihal Pengujian Undang-Undang Nomor 22 Tahun 1999 tentang Pemerintah Daerah. 